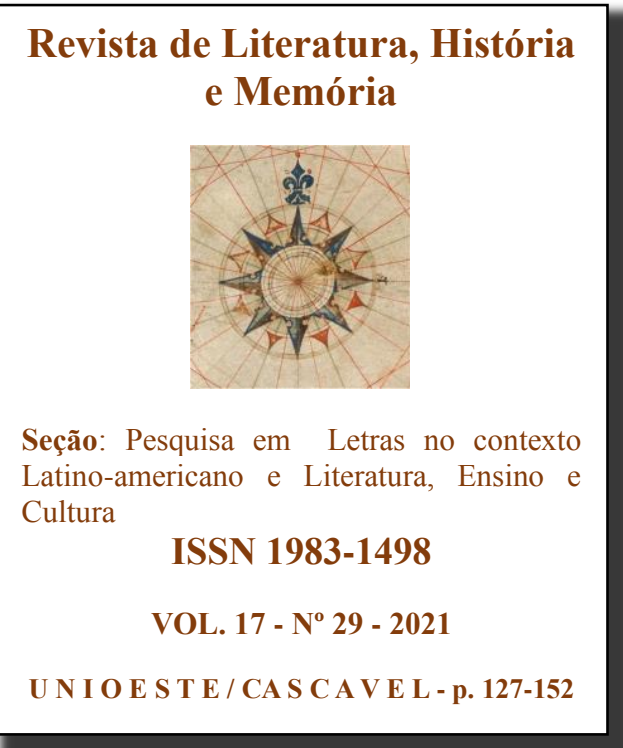

\title{
LITERATURA E HISTÓRIA: MULHERES NEGRAS BRASILEIRAS NOS CORDÉIS DE JARID ARRAES
}

\author{
Literature and history: brazilian black women in cordéis \\ of jarid Arraes
}

\author{
Clarisse Odete Faccio Fronza ${ }^{1}$ \\ Henrique Roriz Aarestrup Alves ${ }^{2}$
}

RESUMO: Este artigo propõe destacar mulheres negras apresentadas como heroínas em literatura de cordel de Jarid Arraes (2017), revisando aspectos relacionados à condição da mulher escrava no Brasil. Além disso, busca-se dar visibilidade à sua participação na luta pela liberdade dos escravos, considerando que, historicamente, foram tratados como objeto/mercadoria e tiveram suas ações suprimidas na história, referido por Chalhoub e Silva (2009) como o paradigma da ausência do negro nos registros oficiais, sobretudo no que tange à participação da mulher nesse processo. Além disso, De Certeau (1994) aponta para táticas e estratégias construídas por posturas de resistências em relações às dominações, marcando, dessa forma, o tempo e o espaço de forma historicamente ativa por grupos sociais, o que pode ser evidenciado nas práticas e ações das heroínas negras e demais personagens dos cordéis. Sendo assim, o livro Heroínas Negras Brasileiras em 15 cordéis, de Jarid Arraes (2017) foi definido como o corpus, justificado pela relevância da temática que apresenta, também por ser produzido em cordel, um gênero literário que, semelhante ao tratamento oficial dado ao protagonismo dessas mulheres, por muito tempo, teve seu valor colocado à margem do que se considerou Literatura e, também, porque tem, como autora, uma mulher negra: elementos que dialogam entre si. A análise da obra possibilita, entre outras, as seguintes conclusões: a mulher negra instruída acerca de sua ancestralidade tem aumentadas suas possibilidades de emancipação e empoderamento, apesar das desigualdades de gênero e raça que persistem; o papel significativo que jovens escritoras negras desempenham na propagação do legado dessas heroínas, abalando, assim, o paradigma da ausência da mulher negra na história oficial da escravidão brasileira.

PALAVRAS-CHAVE: Literatura de Cordel; Subalternidade; Heroínas Negras; Astúcias.

ABSTRACT: This article proposes to highlight black women presented as heroines in Jarid Arraes's (2017) cordel literature, reviewing aspects related to the condition of female slaves in Brazil. In addition, it seeks to give visibility to their participation in the struggle for the freedom of slaves, considering that, historically, they were treated as an object/commodity and had their actions suppressed in history, referred to by Chalhoub and Silva (2009) as the paradigm of absence of blacks in official records, especially with regard to the participation of women in this process. In addition, De Certeau (1994) points to tactics and strategies built by postures of resistance in relation to dominations, thus marking time and space in a historically active way by social groups, which can be evidenced in practices and actions of the black heroines and other characters of the strings. Thus, the book Heroínas Negras Brasileiras em 15 cordels, by Jarid Arraes (2017) was defined as the corpus, justified by the relevance of the theme that presents, also because it is produced in cordel, a literary genre that, similar to the official treatment given to the The leading role of these women, for a long time, had its value placed on the margins of what was considered Literature, and also because it has, as author, a black woman: elements that dialogue with each other. The analysis of the work allows, among others, the following conclusions: the black woman educated about her ancestry has increased

\footnotetext{
${ }^{1}$ Mestre em Letras pela Universidade do Estado de Mato Grosso (UNEMAT), Campus de Sinop, MT. E-mail: clarissefronza@yahoo.com.br

${ }^{2}$ Pós-Doutorado pela Universidade Federal de Minas Gerais (UFMG). Docente e Orientador (UNEMAT), Campus de Sinop, MT. E-mail: henriqueroriz@unemat.br
} 
her possibilities of emancipation and empowerment, despite the gender and racial inequalities that persist; the significant role that young black women writers play in propagating the legacy of these heroines, thus shaking the paradigm of the absence of black women in the official history of Brazilian slavery.

KEYWORDS: Cordel Literature; Subalternity; Black Heroines; Cunning.

Neste trabalho de pesquisa, pretende-se analisar as representações de mulheres negras brasileiras na obra Heroínas Negras Brasileiras em 15 cordéis, de Jarid Arraes. Não é novidade a afirmação de que a História do Brasil fora produzida pelos grupos dominantes; aqui especificamente, sobre a história da escravidão, vale dizer que os responsáveis pelo seu registro foram homens brancos, detentores dos meios de produção e de mão-de-obra escrava, que compravam "bens" (e não pessoas) para aumentar sua capacidade de produção e de obtenção de lucro, reduzindo, pois, seres humanos à condição de coisa, de objetos, o que gerou, consequentemente, a sua invisibilidade como sujeitos históricos.

$\mathrm{Na}$ tentativa de tornar visíveis os escravos que constituíram, juntamente com indígenas e europeus, a base do povo brasileiro, faz-se de fundamental importância uma revisão desses registros históricos, uma vez que saberes, cultura, religião e ações de resistência manifestados pelos escravos são a prova viva de que, apesar de todos os maus tratos e tentativas de extirpar sua humanidade, eles não eram sem religião, sem resistência, sem cultura e sem sentimentos como tentaram fazer crer. Nesse sentido, eles foram sujeitos dinâmicos e ativos desse processo, o que encontra respaldo em Schwartz (2001), que defende que a nova historiografia da escravidão brasileira tenta compreender sua prática e seu funcionamento não apenas como forma de trabalho, mas também como um sistema sociocultural. Silva (2017) identificou, na revisão historiográfica do escravismo criminoso no Brasil, várias concepções, e aponta para aquela vertente que propõe seu entendimento dentro das relações sociais, étnicas e culturais. Esses estudos da nova historiografia se estabeleceram com maior vigor a partir da década de 80 e, a partir deles, revisitou-se o Passado, trazendo, para o Presente, o protagonismo que foi negado a muitos militantes da liberdade, sobretudo às mulheres.

Esse apagamento do escravo negro e, mais enfaticamente, da mulher escrava negra, é designado pelos historiadores dessa vertente da década de 80 como o "paradigma da ausência" (CHALHOUB S.; E SILVA F. T.2009). Nesse sentido, então, ao colocar em evidência a história de 15 heroínas brasileiras negras em cordel, como fez Jarid Arraes (2017), adota-se um expediente oposto a esse paradigma. Apresentar o protagonismo das mulheres tematizadas nessa obra resgata histórias de vida que são inspiradoras e podem favorecer um olhar mais crítico à própria história do país, além de servirem como estratégia de 
empoderamento e consciência crítica a muitas mulheres que, de uma forma ou outra, ainda são subjugadas, seja pelo homem, pela pobreza, pela violência nas ruas ou pela ausência de emprego e moradia.

Dessa forma, o objetivo deste estudo consiste em analisar como estão representadas essas mulheres negras nos cordéis de Arraes, revisando, assim, a condição da mulher escrava no Brasil. Percebe-se que os cordéis dão visibilidade à participação dessas mulheres na luta pela liberdade dos escravos, considerando que, historicamente, foram tratados como objeto/mercadoria e tiveram suas ações suprimidas da história, sobretudo no que se refere à participação da mulher nesse processo.

Com o propósito de conferir visibilidade à bravura e luta de mulheres negras que tiveram suas histórias silenciadas pela História oficial e refletir sobre a condição de objeto a que foram submetidas, selecionou-se a referida obra de Jarid Arraes, que anuncia, em 15 cordéis, o que as mulheres negras sofreram, como foram submetidas, lutaram e constituíram um legado digno de orgulho para essas mulheres da época e suas descendentes de hoje.

As mulheres que têm suas trajetórias contempladas na obra são: Antonieta de Barros, Aqualtunue, Carolina Maria de Jesus, Dandara, Esperança Garcia, Eva Maria do Bonsucesso, Laudelina de Campos, Luisa Mahin, Maria Filipa, Maria Firmina dos Reis, Mariana Crioula, Na Agontimé, Tereza de Benguela, Tia Ciata e Zacimba Gaba.

A trajetória de dor e sofrimento a que foram submetidos os escravos e escravas no Brasil tem início bem antes de sua chegada a esta terra. Da mesma forma que homens, mulheres foram arrancadas de sua terra, tiveram sua identidade anulada e, somadas a outras mulheres e homens, constituíram um amontoado de anônimos nos porões dos navios negreiros ou tumbeiros, como ficaram conhecidos à época, por fazerem tombar tantas vidas na travessia do Atlântico (ELTIS, 2007). Essa designação - tumbeiros - justifica-se por causa das péssimas condições de transporte e maus tratos sofridos durante a viagem nos navios negreiros, como se designassem grandes tumbas ou túmulos flutuantes, uma vez que muitos morriam na travessia e tinham seus corpos, então, lançados ao mar (ELTIS, 2007). As estrofes de Arraes (2017, p.28) em que discorre sobre Aqualtune denunciam essa condição:

Aqualtune foi vendida Em escrava transformada Foi levada para um porto Onde foi então trocada Por moeda, por dinheiro Pruma vida aprisionada. 
Acabou num navio negreiro

Que ao Brasil foi viajar

Nos porões do sofrimento

Muito teve que enfrentar

As doenças e as tristezas

E a maldade a transbordar.

No primeiro verso do fragmento acima apresentado, "Aqualtune foi vendida", está evidenciada a condição de mercadoria da personagem, e em "Pruma vida aprisionada" ratifica-se, consequentemente, a condição de escrava a que fora submetida. Interessante notar ainda a riqueza semântica do verbo transbordar em "E a maldade a transbordar", o qual, associado ao campo semântico de água/navio, sugere que a maldade impetrada aos escravos era tão grande que transgredia as fronteiras do próprio navio.

\section{Aqualtune com seu povo \\ Nos porões muito sofreu \\ Tinham febres e doenças \\ Pela dor que só cresceu \\ Era fome e era castigo \\ Muita gente padeceu.}

(ARRAES, 2017, p. 28).

$\mathrm{Na}$ estrofe acima, também se denunciam as crueldades e sofrimentos vividos nos porões do navio negreiro, em que se encontravam na mesma condição de submetidos, de mercadoria a gerar lucro. A identidade de cada negro e negra, sua função ou posição hierárquica em suas terras originais eram anuladas quando capturados ou comprados, passando, assim, à condição de escravo, mercadoria pertencente aos mercadores ou aos senhores que deles se valiam para as mais inúmeras funções. Aqualtune era também exemplo de escrava nessa situação:

\section{Como filha de um rei \\ Aqualtune era princesa \\ Era no reino do Congo \\ Da mais alta realeza \\ E na tradição que tinha \\ Encontrava fortaleza.}

(ARRAES, 2017, p. 27).

Aqui se observa que o eu-lírico dá ênfase às características identitárias de Aqualtune. Mendes (2002, p. 503) pontua que: 
A identidade é um conceito crucial, porque funciona como articulador, como ponto de ligação entre os discursos e as práticas que procuram interpelarnos, falar-nos ou colocar-nos no nosso lugar enquanto sujeitos sociais de discursos particulares, por um lado, e, por outro, os processos que produzem a subjetividade, que nos constroem como sujeitos que podem falar e ser falados.

A identidade da princesa bem fundamentada em sua tradição cultural possibilitou que ela, apesar da condição de escrava a que também foi submetida, continuasse sendo vista pelo "seu povo" como a princesa. Como outras estrofes, posteriormente, vão revelar, a sua condição na casa grande foi motivo de dor e sofrimento para sua gente que, inclusive, buscava meios de se rebelar para vingar os sofrimentos pelos quais sua princesa foi submetida. Assim, mesmo que para os proprietários ou mercadores todos os escravos fossem mercadoria, para seu povo ela continuava sendo a princesa, ou seja, uma líder cujas ações deveriam ser apoiadas por seus súditos

Em razão de rivalidades entre reinos, teriam ocorrido muitas guerras e, em uma delas, o rei do Congo, pai da princesa Aqualtune, foi derrotado:

Na disputa dessa guerra

Seu pai foi derrotado

E vendidos como escravos

Foi seu reino humilhado

Mais de dez mil lutadores

Igualmente enjaulados.

(ARRAES, 2017, p. 27).

Esses versos evidenciam que não importava a condição de guerreiro ou princesa pois, uma vez subjugados por tribo rival (ou capturados de outras formas pelos traficantes de escravos), passavam à condição de mercadoria da mesma forma como ocorrera também com a rainha $\mathrm{Na}$ Agontimé e a princesa Zacimba Gaba:

A rainha Agontimé

Como escrava foi vendida

E parou no Maranhão

Onde assim foi escolhida

Para ser renomeada

C' outro nome batizada

De direitos foi tolhida.

Foi Maria Jesuína

$\mathrm{O}$ nome que lhe impuseram

E com muita crueldade

De escrava lhe fizeram [...]

(ARRAES, 2017, p. 128-129) 
A rainha Agontimé tem seu nome, índice de identidade por excelência, trocado. Esse ato, para além de tirar sua posição de rainha e submetê-la às mesmas condições de mercadoria dos outros escravos, representa também uma tentativa ferrenha de apagamento e silenciamento de suas origens. Assim, a condição de objeto dos escravos mais uma vez se evidencia, como se não tivessem histórias, memórias, tradição e sentimentos:

\section{Zacimba Gaba foi seu nome \\ Uma princesa escravizada \\ Vinda de Cabinda, Angola \\ Pro Brasil foi sequestrada \\ No estado do Espírito Santo \\ Acabou desembarcada. \\ Zacimba Gaba foi descrita \\ Logo quando foi comprada \\ Como uma "negra rebelde" \\ Que até foi recapturada \\ Depois de tentar fugir \\ Foi duramente castigada.}

A história é farta de relatos que garantem o entendimento do tráfico de pessoas como próspero negócio na sociedade que compreendeu os séculos XVI e XIX. Por consequência, a condição de "coisa" ou mercadoria dos negros capturados implicava, por sua vez, em condições desumanas de travessia, como se observa no exposto pelo historiador David Eltis:

Fosse qual fosse o caminho percorrido, as condições a bordo refletiam o status de excluídas que marcava as pessoas aprisionadas no porão. Nenhum europeu - fosse condenado, servo temporário ou imigrante livre miserável - jamais foi submetido ao ambiente que recebia o escravo africano típico no momento de embarque. Eram separados por sexo, mantidos nus, amontoados, sendo os homens acorrentados por longos períodos (ELTIS, 2007, s.p).

Nos trechos dos cordéis acima trazidos, tem-se a representação desses fatos que a história relata; porém, ao caracterizar esses episódios cruéis de violência associando-os a nomes em particular no cordel, a gravidade do dano parece ficar ainda mais acentuada, pois afinal o texto poético evidencia que tinham nome e história, ou seja, eram sujeitos e seres humanos.

A escravidão para a mulher negra representou, como se não fossem já suficientes todos os sofrimentos comuns aos do homem, outras formas de violência, como a exploração sexual de seu corpo que, considerando a dinâmica da escravidão, não lhe pertencia (GIACOMINI, 
1988). Assim, na condição de mercadoria:

Quando se tratava de mulher, os seios eram bem examinados pois poderia vir a servir como ama de leite e bem assim as nádegas. Tinha-se interesse em negras do traseiro grande, bem servido de carnes, porque isso era - diziam indício de força, saúde e qualidade de boa parideira, capaz de dar novos escravos ao senhor (MACEDO, 1974, p. 32).

Essa situação está claramente expressa nas estrofes do cordel de Arraes (2017, p. 28 29), que dão continuidade ao destino da princesa Aqualtune:

Foi vendida como escrava

Chamada reprodutora

Imagine o pesadelo

Que função mais redutora

Pois seria estuprada

De escravos genitora.

Sua principal função

Seria a de procriar

Estuprada na rotina

Muita dor pra suportar

Imagine uma princesa

Isso tudo enfrentar.

Neste sentido, Giacomini (1988, p.87) considera que "reduzir a escrava à condição de "coisa", é negar-lhe toda e qualquer subjetividade, pois que a escravidão se constrói sobre a base da indiferenciação dos submetidos". Nesta perspectiva, "mucamas, amas-de-leite, cozinheiras, bordadeiras, lavadeiras e engomadeiras foram incorporadas ao espaço privilegiado das senhoras, ou seja, à esfera doméstica" (p. 91). Dentro das casas dos senhores, então, os olhares de vigília não foram atenuados, exigindo-se, ademais, sua disponibilidade para todas as tarefas, numa continuidade sem fim. Esse papel imputado às mulheres negras pode ser claramente observado nas estrofes que versam sobre a Mariana Crioula (ARRAES, 2017, p. 117-118):

Foi Mariana Crioula Nome para se guardar Era escrava com função De mucama e costurar Vivia na Casa-Grande Mandada para trabalhar.

A senhora das fazendas Que da dor se enricava 
Era Francisca Xavier

E o bolso transbordava

Pelo sangue dos escravos

Que nas terras maltratava.

Nesta estrofe, tem-se citado o nome da senhora, dona das fazendas, "que da dor se enricava": Francisca Xavier. Essa denúncia personalizada da classe opressora raramente é vista em textos históricos. Também se chama a atenção para a expressividade da linguagem poética alcançada com o emprego do verbo transbordar. $\mathrm{O}$ eu-lírico parece ter a pretensão de evidenciar a ligação direta entre lucro, enriquecimento e maus-tratos corporais sofridos pelos escravos. Quanto mais se castigava, mais se aumentava a produtividade a ponto de o bolso transbordar, alcançando lucros de grande monta com o resultado do trabalho forçado dos escravos.

A presença circunscrita aos domínios domésticos de seus proprietários implicou em muitos desdobramentos graves e sofríveis para a mulher escrava. Um deles diz respeito à sexualidade da escrava, pois sua condição de "propriedade" favorecia ao seu senhor apropriarse de seu corpo, que era entendido como livre de restrições de qualquer natureza, como da questão da finalidade de procriação, das normas éticas e morais impostas por religião. Assim, a escrava era "desnudada de toda série de funções que são reservadas às mulheres brancas, para ser apropriada num só aspecto: objeto sexual" (GIACOMINI, 1988, p.62), o que caracteriza estupro institucionalizado. Esse abuso que se impôs às tantas mulheres, nos cordéis de Jarid Arraes, é denunciado, como no caso de Zacimba Gaba:
A inveja de Trancoso
Era porca de enojar
Foi por isso que manteve
O castigo sem cessar
E Zacimba foi cativa
Pra ele a abusar.
Trancada na Casa-Grande
Zacimba era estuprada
Por Trancoso e capataz
Era tão violentada
Que os irmãos já se uniam
Com revolta levantada.

(ARRAES, 2017, p. 158-159).

Portanto, não bastava a exploração da mulher como serviçal de forma ilimitada, pois era preciso ainda dispor de seu corpo, já que nem isso lhe pertencia. Dessa forma, a exploração sexual pelos senhores foi naturalizada, e expõe, claramente, um elemento 
diferenciador entre a condição da mulher negra, do homem negro e também da mulher branca: a negra é explorada como escrava e como mulher.

A possibilidade de resistência ou reação às adversidades a que os escravos foram submetidos parecem mais acentuadas no texto literário, uma vez que o tom de revolta aparece mais explicitamente; diferente de textos históricos, sobretudo dos anteriores à nova historiografia da escravidão, que propõe exatamente a exposição e análise das formas de resistência empreendidas. Observa-se, na estrofe acima apresentada, a manifestação de uma revolta coletiva devido à violência sofrida por Zacimba, colocando em destaque a força da identidade coletiva.

Gonzalez (1982, p. 97) observa que "ser negro e mulher no Brasil, é um objeto de tripla discriminação, uma vez que os estereótipos gerados pelo racismo e pelo sexismo a colocam no mais baixo nível de opressão”. Assim, busca-se ressaltar a importância de vincular raça, gênero e identidade como pauta de importantes debates e movimentos na atualidade, representando uma tentativa de alterar condições/fenômenos historicamente determinados pelas condições a que essas mulheres foram submetidas no período colonial.

Para aprofundar a gravidade dos danos cometidos à mulher negra na escravidão, importa ainda mencionar que lhe competia também gerar novos escravos; porém, em geral, não lhe era facultado o direito de criar seus filhos que, não raras vezes, pela demora em ser útil como "bem" rentável ou se tornar apto para o trabalhado escravo, era abandonado ou entregue a instituições de caridade, não se tendo deles mais notícias. As estrofes abaixo, sobre a princesa Aqualtune, evidenciam mais essa forma de violência que se fez presente na vida de tantas outras mulheres negras:

\author{
Foi levada a Porto Calvo \\ Pernambuco, a região \\ E vivendo como escrava \\ Enfrentou a solidão \\ Os castigos e torturas \\ No seu corpo a agressão \\ Imagine quantos filhos \\ Aqualtune teve então \\ Tudo fruto do estupro \\ Fruto de violação \\ E ainda eram tomados \\ No meio de um sopetão.
}

(ARRAES, 2017, p. 28-29).

Atente-se à palavra "sopetão" que aqui pode significar tanto "de repente" quanto "em 
meio a atos de violência", como agressões verbais e corporais, indicando a insegurança da mulher quanto à permanência de seu filho junto a si, o qual poderia ser tirado de perto dela sem qualquer aviso e a qualquer momento. A denúncia maior dos versos, no entanto, é a da violação do corpo da escrava, considerado mercadoria e objeto sexual pelo seu senhor.

Em contrapartida, após ter dado à luz, tornava-se, potencialmente, uma ama de leite. Muitos são os autores que relatam mais essa violência impetrada contra a mulher negra que, além de ser obrigada a amamentar os filhos da senhora branca, poderia ser alugada para terceiros. Magalhães e Giacomini (1983, p. 80) relatam que à mãe preta, para que cuidasse do filho branco, era imposto, pelos seus donos, o afastamento de seu filho, pois a "mercadoria escrava leiteira" era mais lucrativa sem sua cria, tirando, assim, a "única possibilidade de relação familiar acessível ao escravo" ${ }^{3}$.

Assim, ratifica-se que a escrava foi tomada como objeto sexual, ama de leite, saco de pancada das sinhazinhas, vítima do ciúme e da violência cruel da mulher branca preterida, responsável pela iniciação sexual dos sinhozinhos pois, além de escrava, era mulher, e essa maneira de vivenciar sua condição de mulher não se deu com isenção de classe ou de cor (GIACOMINI, 1988).

Spivak (2010), em suas reflexões sobre as possibilidades de fala dos sujeitos subalternos, observa que os processos escravistas coloniais foram, claramente, métodos concretos, cruéis e extremamente violentos que visavam desumanizar e privar as(os) negras(os) do domínio de seus corpos e mentes. E, para reforçar o entendimento da condição de objeto como acima referido, aponta-se, ainda, a sua afirmação direcionada à mulher nesse processo: "Se no contexto da produção colonial, o sujeito subalterno não tem história e não pode falar, o sujeito subalterno feminino está ainda mais profundamente na obscuridade" (SPIVAK, 2010, p. 66).

Em recente artigo Como resistir em tempos brutos, a jornalista e escritora Eliane Brum (2018) escreveu: "Jamais se esqueçam que a primeira vitória da opressão é sobre a subjetividade". Com essa afirmação que também soa como um apelo à reflexão, dá-se início a este tópico em que se apresentam estrofes de cordéis relacionados ao silenciamento dos atos de mulheres negras e à ausência de suas trajetórias de vida nos textos oficiais que contam a História do Brasil, sobretudo, no que compete à escravidão e atuação da mulher negra. Luisa Mahin e Mariana Crioula protagonizaram situações que, a despeito de as constituírem como

\footnotetext{
${ }^{3}$ As amas negras, muitas vezes, eram obrigadas a "depositarem" seus filhos na Roda dos Expostos ou dos Enjeitados a mando do seu dono, para a manutenção deste negócio tão rentável (MAGALHÃES e GIACOMINI, 1983). Não se pode ignorar que esta ação, praticada com naturalidade pelos senhores, representou sacrifício e violência incapazes de serem, objetivamente, representados.
} 
sujeitos partícipes da história, são silenciadas nos textos que são ditados, produzidos pelas vozes enunciativas do dominador.

Para Spivak (2010), a ausência da palavra (do discurso) é o fator primordial que gera a subalternidade. Para ela, a condição de subalternidade é a condição de silêncio e, nesse sentido, associa-se, aqui, o exposto à mulher negra que foi subjugada e teve sua vida transformada em dor e sofrimentos constantes, contra os quais ela se voltou e engendrou, junto dos seus, meios para se libertar. Embora essa conduta tenha sido duramente repreendida com violência de toda forma quando em curso, também se caracteriza, como outra forma de violência, o silêncio sobre esses atos nos registros que apresentam a historiografia oficial da escravidão.

Os registros em cordel produzidos por Arraes (2017) evidenciam que não faltava voz propriamente dita para essa mulher subalterna falar, mas os textos que a representaram oficialmente como objeto não lhe concederam protagonismo, e assim ocuparam esse espaço que lhe caberia para expressar seu grito, sua história, sua subjetividade, anulando, assim, a voz destas mulheres. Esse entendimento se respalda em Spivak (2010) quando observa que os relatos de representação (entendido como o discurso daquele que "fala por") relacionados à subordinação do representado constroem a "não-voz" do sujeito subalterno. Abaixo, então, o cordel retrata Luisa Mahin e seu processo de silenciamento:

\section{Apesar de tudo isso \\ E de tudo que lutou \\ Essa mulher imponente \\ Muito se silenciou \\ Pois ainda não se conta \\ Tudo que realizou. \\ Mas apenas sua memória \\ É forte o suficiente \\ Pra mexer na estrutura \\ Dessa gente incoerente \\ Que não fala a verdade \\ Sobre o negro insurgente.} (ARRAES, 2017, p. 91).

Observa-se, nos três versos finais da primeira sextilha apresentada, o verbo "silenciar" empregado no Pretérito Perfeito do Indicativo, consolidando a ação desempenhada pelo discurso oficial. Assim, mesmo que se reconheça a intenção de fazer jus à trajetória de Luisa Mahin, os versos sugerem que muito do que essa heroína fez ainda está para ser pesquisado e trazido à luz pois, supostamente, ela estaria ausente dos registros oficiais. 
$\mathrm{Na}$ segunda estrofe, reitera-se o valor da memória como condição que possibilita à autora se autorrepresentar como sujeito histórico nesse processo na medida em que, como sua biografia confirma, procura identificar-se como membro da categoria genérica de seus representados (SPIVAK, 2010). Pesquisando suas raízes, tem acesso a informações que o discurso oficial não lhe apresenta, como as ações que foram silenciadas. Por isso considera-se acertado o emprego do adjetivo "incoerente" para caracterizar os autores desse discurso que, para ela, não é verdadeiro.

A memória faz-se instrumento de identidade na medida em que registra características, fatos e feitos. A lembrança de quem experienciou determinada realidade opressora e violenta, transformada em legado, vale muito mais que os estereótipos e pré-conceitos (negro é preguiçoso, vagabundo, cachaceiro, traiçoeiro, violento, afeito a cometer crimes) transmitidos pela elite e outros veiculadores de ideologias dominantes. No cordel, a memória (legado cultural) assume maior valor que discursos discriminatórios e ignorantes sobre os negros.

Acerca de outro adjetivo empregado, ou seja, "insurgente", considera-se oportuno apresentar as conclusões de Iraneide Soares da Silva em Breves leituras da historiografia sobre o escravismo criminoso contra os africanos e seus descendentes no Brasil, que apresenta um aporte teórico que permite visão ampla acerca dos diferentes entendimentos que esse fenômeno gerou por historiadores em distintos períodos. De suas leituras, destaca três vertentes principais:

A primeira que busca uma visão paternalista, seguida por Gilberto Freyre; a segunda que traz uma discussão meramente econômica do escravo que - em linhas gerais, muitas vezes, entende-o como objeto, seguida pelo grupo de historiadores e cientistas sociais formados na Universidade de São Paulo, como Caio Prado Júnior, Emília Viotti e outros; e a terceira vertente busca compreender o escravo como um agente de sua própria história, seguido por Silvia Lara, Sidney Chalhoub, Solange Rocha e outros (SILVA, 2017, p. 42).

O entendimento da segunda vertente, de que "o escravizado não tinha personalidade, pois era tão somente um mero instrumento, uma vez que a escravidão tirava sua capacidade de pensar e de se ver como pessoa, como sujeito atuante e lutar contra a sua própria condição de escravizado" (SILVA, 2017, p.49), é refutado por Jarid Arraes nos dois versos finais, quando reitera que a fala "dessa gente" é incoerente, pois não enunciam a verdade sobre o negro "insurgente". No geral, denota-se o entendimento proposto pelo adjetivo como negativo; no entanto, neste contexto, o verso da cordelista caracteriza-o positivamente, evidenciando, assim, as manifestações dos negros em prol de sua liberdade, tão deliberadamente silenciadas por essa "gente incoerente". Esses entendimentos também são 
evidenciados nas estrofes selecionadas do cordel que trata de Mariana Crioula:

\author{
E assim como Mariana \\ Muitas outras existiram \\ Que lutaram e lideraram \\ Bravamente resistiram \\ Essas heroínas negras \\ Na História emergiram. \\ Mesmo que pouco lembradas \\ Elas são inspiração \\ Pois nos contam a verdade \\ Sobre a história da nação \\ Onde os negros guerrearam \\ Pela enfim libertação. \\ Se na escola não se ensina \\ E se na Tv não se mostra \\ Eu escrevo esse cordel \\ E espalho essa proposta \\ Compartilha quem entende \\ E quem da verdade gosta.
}

(ARRAES, 2017, p. 122).

Nos dois últimos versos da primeira estrofe apresentada, o verbo "emergiram" corrobora a intenção do discurso de silenciamento da atuação da mulher negra. Depreende-se que as ações efetivadas por ela e tantas outras, a ponto de serem consideradas heroínas, não apareciam, pois estavam abaixo do visível, como se estivessem escondidas e só possíveis de serem conhecidas pela ação de pesquisadores/escritores que se dispuseram a buscar essas histórias e trazê-las ao conhecimento.

$\mathrm{Na}$ segunda estrofe, reitera-se o entendimento de que a história contada pelos atos heroicos dessas mulheres merece crédito, sendo referida pela cordelista como verdade, como no cordel de Luisa Mahin, que se diferencia do discurso oficial da história "dessa gente incoerente que não fala a verdade”. Assim, escola e mídia são apresentadas pelo eu-lírico como os veiculadores de ideologia dominante e, portanto, silenciadoras das vozes dos feitos dos negros e negras desse país. Na observância dos sentidos propostos pelo uso da palavra verdade agregada a diferentes emissores (essa gente incoerente e elas são inspiração), merece status de verdadeira aquela que enuncia o negro como agente de sua história. Inclusive, ao se observar o exposto na última estrofe, a autora do cordel faz clara referência ao papel da Literatura, indicando que escreve o cordel com a intenção de espalhar o sujeito negro, em especial, a mulher, como aquela que guerreou pela liberdade, o que, comumente, não está presente no livro didático e na televisão, veículo ainda relevante na propagação de informação 
e conhecimento no país. Assim, o domínio da linguagem poética apresentada nos cordéis pela autora caracteriza um expediente de resistência ao silenciamento das vozes dessas mulheres negras, e seu cordel configura-se como um metacordel, cujo papel é o de difusor da "verdade", ou seja, de outra interpretação da história e de seus heróis.

Na presente análise serão evidenciadas as ações protagonizadas por mulheres negras, seja na condição de escravas, forras ou livres que contrariam a ideia de resignação e ou passividade com que a população negra teria se comportado diante da violência que lhe foi imposta ao ser transformada em mercadoria e explorada das mais diversas formas.

Do entendimento favorecido pelos estudos de Silva (2017), em que expõe as vertentes principais da historiografia da escravidão, as estrofes de cordéis apresentam mulheres em ação e, portanto, em sintonia com o escopo da terceira vertente, que é aquela que busca compreender o escravo como um agente de sua própria história. A autora observa que os pesquisadores dessa vertente propunham uma revisão historiográfica que combatia a imagem do escravo(a) como mera mercadoria de um sistema econômico, propondo seu entendimento dentro das relações sociais, étnicas e culturais:

Se os autores da segunda vertente entendiam que 'o escravizado não tinha personalidade, pois era tão somente um mero instrumento, uma vez que a escravidão tirava sua capacidade de pensar e de se ver como pessoa, como sujeito atuante e lutar contra a sua própria condição de escravizado', implica negar a esse trabalhador escravo a sua condição de sujeito histórico; já os estudos que começaram a se estabelecer a partir da década de 80 , os da terceira vertente, 'analisam o trabalhador negro escravizado na sua diversidade de condição jurídica, como um agente de sua vida, que de algum modo, lutava por uma vida menos oprimida, menos violenta. E para fugir da linha dura do escravismo, procurava meios para libertar-se do cativeiro' (SILVA, 2017, p.49-50, grifos da autora).

Nesse sentido, revisar aspectos relacionados à condição da mulher escrava no Brasil, como Arraes realiza em seus cordéis, associa-se ao propósito de importantes pesquisadores filiados a essa mais recente historiografia da escravidão que, conforme apontado por Chalhoub S.; e Silva F. T. (2009), propõem abalar o "paradigma da ausência", especialmente no que se refere à participação da mulher nesse processo. Ao legitimar a mulher negra como agente construtor de sua própria história, fomenta-se seu empoderamento. Na medida em que foram ganhando algum espaço enquanto serviam seus senhores, elas buscavam subterfúgios para resistir, reunir dinheiro e comprar a liberdade de marido ou de filhos. Atualmente, a maioria delas continua com trabalhos tidos como subalternos, precisando se valer de mecanismos diversos de resistência para sobreviver em meio às adversidades em uma sociedade que ainda se comporta como se os trabalhos mais precários e mal remunerados 
fossem naturalmente atribuições de mulheres negras, o que alude, indubitavelmente, ao período da escravidão.

Os termos "subterfúgios" e "mecanismos" estão em consonância com as considerações de De Certeau (1994) sobre as "artes de fazer", na medida em que aproximar-se-iam dos meios astuciosos empregados pelas mulheres negras na tentativa de se libertarem da condição de escravas. O teórico diferencia dois conceitos-chave: táticas e estratégias. Ele denomina de estratégia "o cálculo (ou a manipulação) das relações de forças que se torna possível a partir do momento em que um sujeito de querer e poder (uma empresa, um exército, uma cidade, uma instituição científica) pode ser isolado" (DE CERTEAU, 1994, p. 99). O princípio fundamental para a validação das estratégias seria a posse de um "próprio", caracterizado como "uma vitória do lugar sobre o tempo", sendo o domínio de um espaço físico ou simbólico que legitima as estratégias dos grupos ali estabelecidos. Para o autor "o poder é uma preliminar do saber", que se produz através dessa relação (DE CERTEAU, 1994, p.99).

Já as táticas compreendem as ações calculadas e determinadas pela ausência de um próprio, ou seja, de um território. Nesse sentido, as táticas só existem em função do outro; jogam com o lugar/terreno que lhe é imposto pelas estratégias, não dispondo de forças para manter a si mesmas ou um projeto global. Operam cautelosamente, aproveitam as ocasiões e baseiam-se unicamente nos azares do tempo; suas principais formas de ação são as astúcias. As táticas são as "artes dos fracos", considerando que, quanto menor o poder, maior é a possibilidade do indivíduo para articular ações astutas (DE CERTEAU, 1994).

A mulher escrava mostrou-se, pois, habilidosa para adotar "artes de fazer" diversas de enfrentamento, considerando-se, para isso, o exposto por Karash (2000), a qual afirma que muitas não escolhiam a violência como forma de mudar de situação, mas tentavam fazer duas coisas ao mesmo tempo: agradar aos seus senhores para obter alforria e melhorar suas condições de servidão, como se pode identificar nas estrofes sobre Esperança Garcia:

\footnotetext{
Nessa carta ela dizia

Que vivia a apanhar

Uma vez sendo jogada

Com intento de matar

Foi caindo do sobrado

Mas se deu para escapar.

[...]

Esperança disse ainda

Que queria batizar

A menina era criança

Mas a fé era exemplar

$\mathrm{E}$ a religião cristã
} 
Ela estava a professar.

E falou de outras mulheres

Querendo se confessar

Que do mesmo jeito dela

Precisavam de contar

Seus pecados escondidos

Para o padre perdoar.

Porque lá onde ela estava

Não se tinha a confissão

Nem batismo e nem missa

Que era assim religião

E Esperança argumentava

Que isso era confusão.

Foi usando destes pontos

Seu exemplo de esperteza

Por fazer da fé cristã

Argumento de clareza

Para ver se conseguia

Do governo uma presteza.

(ARRAES, 2017, p. 60-61).

Inicialmente, convém dizer que, anterior à situação que se apresenta, Esperança Garcia era escrava de padres jesuítas, alcançou permissão para se casar e, dessa união, tem uma filha; fora alfabetizada pelos padres, o que não era, por sua vez, consentido a escravos. Ao ser transferida e separada do marido, a sua nova condição era bem pior que a anterior, o que resultou em sua iniciativa de escrever uma carta ao presidente da província do Piauí. Chama a atenção que, buscando meios de obter favor, não só reclama dos castigos físicos, mas reproduz o discurso religioso do opressor, numa espécie de porta-voz de um coletivo de mulheres que "Precisavam de contar/Seus pecados escondidos". Mostra-se insatisfeita pela impossibilidade de acesso a sacramentos da religião que alega adotar, o que seria reforçado pelo emprego do substantivo "confusão". Também faz considerações sobre sua filha, uma criança ainda: "Mas a fé era exemplar/E a religião cristã/Ela estava a professar", evidenciando uma clara tentativa de agradar às autoridades a quem se dirigia e deles obter alcance da causa granjeada.

Os versos iniciais da última estrofe apresentada - "Foi usando destes pontos/Seu exemplo de esperteza/Por fazer da fé cristã/Argumento de clareza" (p. 60) - sugerem entendimento semelhante ao de De Certeau (1996) a respeito da tática como arte do fraco. A sua iniciativa em escrever a carta, por certo, objetivava alcançar melhores condições de servidão; porém, esse intento não poderia ser explícito, manifestando, assim, incômodo pela 
ausência de padres, através dos quais poderia teria acesso aos ritos religiosos católicos. Esse discurso poderia favorecer um olhar mais complacente à sua causa, diferentemente de uma queixa direcionada somente aos castigos físicos.

Karash (2000) observa também que, em geral, as mulheres se valiam de formas menos violentas de resistência, como rituais espirituais para controlar os seus senhores, diminuição do ritmo de trabalho, doenças fingidas para evitar o trabalho duro, comportamentos autodestrutivos, etc. A princesa Zacimba Gaba ilustra bem a oposição estabelecida entre astúcias e estratégias propostas por De Certeau (1996), como se explica após a leitura do excerto em que ela oferece cantos aos orixás e tramava saídas em silêncio:
Mas com medo da revolta
Trancoso mandou dizer
Que se algo acontecesse
A princesa ia morrer
$\mathrm{E}$ com isso aquietou
$\mathrm{O}$ que ia acontecer.
Pelas noites, da senzala
Um alto canto se escutava
Era a princesa Zacimba
Que aos orixás cantava
Por justiça e liberdade
Todo dia ela clamava.
Ao longo do tempo duro
Zacimba se fortaleceu
E sofria com seu povo
Por tudo que aconteceu
Mas tramava uma saída
$O$ final triunfo seu.

(ARRAES, 2017, p. 159).

A princesa Zacimba era estuprada por seu dono, chamado de Trancoso, e por seu capataz, razão pela qual seus irmãos se uniram em revolta levantada. Porém, a ameaça de morte da princesa anunciada por Trancoso fez aquietar o levante temido. Como forma de resistência a essa condição, Zacimba cantava aos orixás e a eles clamava por justiça e liberdade, pois se sabia injustiçada pelo abuso de seu corpo e pela sua liberdade tolhida, além de ter sido brutalmente separada de seu povo e de sua terra original, em que exercia a função social de princesa.

Os dois últimos versos do fragmento acima apresentado ratificam a condição de nãopassividade da mulher escrava, de resistência estabelecida, pois tramar uma saída parece ser ação que exemplifica o que De Certeau (1996) considera ser como um modo de resistência 
criativa construída através da micro-resistência. Mott (1988) aponta para o fato de que que muitos senhores temiam envenenamentos passíveis de serem praticados por mucamas ou escravas circunscritas ao espaço da Casa-Grande, o que fora tramado e executado por Zacimba, com a ajuda de seu povo:

\author{
Com ajuda do seu povo \\ Fez um veneno mortal \\ Da cabeça de uma cobra \\ Que era disso especial \\ Com o pó desse veneno \\ Fez um plano crucial. \\ Era aos poucos, todo dia \\ Que o veneno ali botava \\ Na comida de Trancoso \\ Que jamais desconfiava \\ Lentamente adoecendo \\ Do veneno que tomava. \\ Quando um dia finalmente \\ $\mathrm{O}$ esperado aconteceu \\ O senhor da Casa-Grande \\ Entre gritos faleceu \\ E a gente da senzala \\ Pra revolta se mexeu. \\ Invadiram a Casa-Grande \\ E Zacimba os liderou \\ Segurando uma peixeira \\ A princesa ali lutou \\ E os servos de Trancoso \\ No confronto derrotou.
}

(ARRAES, 2017, p. 159-160).

A ação narrada nessas estrofes expõe a postura ativa dessa escrava princesa que planeja e lidera uma revolta, o que dialoga com o que afirma "O poder se acha amarrado à sua visibilidade. Ao contrário, a astúcia é possível ao fraco e, muitas vezes apenas ela, como último recurso: quanto mais fracas as forças submetidas à direção estratégica, tanto mais esta estará sujeita à astúcia” (DE CERTEAU, 1996, p. 101). Trancoso - sujeito de querer e poder manipula as relações de força que se localizam no terreno do visível das relações sociais, quando, por exemplo, ameaça Zacimba de morte e tem conhecimento das intenções de revolta dos seus irmãos. Já o plano do envenenamento arquitetado estaria na instância referente ao fraco, aqui representado pela escrava princesa e seus irmãos, os quais se mostraram mais astutos na medida em que foram mais submetidos pela força estratégica do opressor. $\mathrm{O}$ 
encaminhamento do desfecho de Trancoso deu-se demorada e silenciosamente, oportunizando o alcance do resultado das ações cautelosamente calculadas - a fuga e a liberdade - que favoreceram, por sua vez, novas formas de fazer, outras táticas colocadas em outros espaços de movimentação, de ação e de luta.

Assim como Zacimba, um sem número de mulheres negras, rodeadas de toda forma de opressão, planejaram mecanismos de resistências através de astúcias no tempo que foram decisivas em fugas e/ou obtenção de informações sobre vendas e transferências por eles tidos como indesejáveis. Além disso, providenciavam suprimentos, auxílio aos escravos em fuga ou aqueles interessados em escapar:

Com coragem e ousadia

Os navios ela atacava

Ia com os seus guerreiros

E da escuridão pulava

Libertando os cativos

Que pro quilombo levava.

Assim como foi Zacimba

De Angola escravizada

Muitas outras também foram

No Brasil que castigava

Mas o espírito de luta

Nenhum branco lhes matava.

(ARRAES, 2017, p. 161).

O espírito de luta que nenhum branco matou autoriza a autora dos cordéis a falar delas como heroínas, pois se mostraram protagonistas de seus feitos históricos com o intuito de conquistarem "voz" e dignidade em uma sociedade fortemente escravagista, o que custara muitas vidas de negros e negras. Também consta que as mulheres (escravas, forras ou livres) empenhavam-se em manter a integridade de arranjos familiares quando podiam acontecer, além de procurarem zelar pela riqueza e originalidade de sua cultura. Por isso elas podem ser definidas como os primeiros agentes da luta por emancipação das comunidades afrodescendentes.

Entretanto, a realidade experimentada pela mulher negra que vivera em período anterior à Lei Áurea não se dissipa. Mulheres negras e escravas estavam colocadas em um nível social inferior tanto por serem mulheres quanto por serem negras e, até então, também escravas; ser mulher, dentro de uma sociedade extremamente preconceituosa, opressora e sexista, significava reunir todos os elementos favoráveis à exploração, tanto econômica quanto sexual, e também ser o alvo de humilhações da sociedade nos seus diferentes 
segmentos" (GIACOMINI, 1988). Não importava que fosse "livre". O entendimento dessa condição da mulher à época ainda chega aos dias de hoje quando se percebe a necessidade de se estabelecer políticas de enfrentamento à herança que a mulher pobre e negra ainda carrega.

Durante três séculos as mulheres negras foram feitas escravas no Brasil e, então, a partir de 13 de maio de 1888, passaram de escravas a mulheres livres. Pode-se dizer que essa liberdade, no entanto, veio acompanhada de um infindável rosário de adversidades, pois as mulheres negras alforriadas sofreram dupla estigmatização: pela condição de mulher e pela condição racial que parecem ter determinado, ainda, um terceiro estigma: o da pobreza. Gonzales (1982, p. 97) ratifica o exposto ao afirmar que "ser negro e mulher no Brasil [...] é um objeto de tripla discriminação, uma vez que os estereótipos gerados pelo racismo e pelo sexismo a colocam no mais baixo nível de opressão". Se elas carregavam as marcas da violência física desde os tempos da escravidão, resultado das punições a que eram submetidas, vão, gradativamente, sendo marcadas por outras experiências de dor, de enfrentamento, de luta e de submissão como: as oportunidades desiguais de trabalho e renda se comparadas com outras mulheres brancas; as precárias condições de moradia que, desde a "libertação", demarcaram as fronteiras periféricas dos espaços urbanos para essa população; a necessidade de sujeitar-se a trabalho semiescravo para sustentar seus filhos e marido que não encontra emprego. Essas são algumas das situações por elas enfrentadas e que continuam fazendo parte da realidade de muitas mulheres negras em todo país.

Outra forma também adotada por um representativo número de mulheres forras é apresentada por Rabelo:

A maioria dessas mulheres era analfabeta, de cor parda ou negra e vivia do pequeno comércio, como quitandeiras, donas de tavernas, artesãs, costureiras e de suas 'agências', isto é, do trabalho esporádico como cartomantes, feiticeiras, parteiras, cozinheiras, lavadeiras, engomadeiras etc. A fim de completar suas rendas, muitas se entregavam à prostituição (RABELO, 2002, p. 5, grifos do autor).

A condição experimentada por Laudelina de Campos e Maria Carolina de Jesus contribui para a exemplificação do exposto por Rabelo:

\author{
I. Laudelina de Campos \\ Tinha apenas sete anos \\ Quando foi ser Casa-Grandeeira \\ Empregada de família \\ Como profissão primeira \\ Mas ainda era tão cedo \\ Para ser trabalhadeira!
}


Imagine que terrível

Era ainda uma criança

Mas limpava e cozinhava

Sem a chance da mudança

Pois nesse país racista

Não havia outra esperança.

$$
[\ldots]
$$

Nascida em Poços de Caldas

Laudelina era mineira

Mas mudou para São Paulo

Onde também foi faxineira

E se consolidou em Santos

Como grande pioneira.

\section{[...]}

Por mais de quarenta anos

Laudelina trabalhou

Como empregada doméstica

Até que por fim parou

E abriu o seu negócio

Que feliz realizou.

Ela vendia salgados

E abriu uma pensão

Saía em dias de jogo

Pra vender à multidão

Nos estádios da cidade

Com garra e dedicação.

(ARRAES, 2017, p.77-78, 80).

A trajetória de Laudelina é ilustrativa da condição de inúmeras mulheres que, após a abolição da escravidão, continuaram experimentando situações de grande exploração. Aos sete anos sua instrução não fora priorizada, precisando submeter-se ao trabalho doméstico de casa-grandeeira exaustivo, ou seja, quase três décadas depois da "libertação" dos escravos uma criança ainda em relativa tenra idade tem que se submeter ao trabalho, o que permite afirmar que as condições pós-escravidão não ofereceram alternativas diferentes para os descendentes de escravos. A própria expressão que designa o ofício - casa-grandeeira remete ao fardo da escravidão, pois sequer o nome fora alterado. Essa condição a que Laudelina fora exposta, no entanto, favorecera aparecimento em sua consciência questões sobre essa problemática, tornando-se militante em favor da defesa dos direitos das empregadas domésticas: 
Era a dor da servidão

O racismo dominava

Espalhando humilhação.

Sua mãe era solteira

Pela igreja excomungada

Pois o homem era casado

E findou abandonada

Com a filha pra criar

E por muitos execrada.

$$
\text { [...] }
$$

Na favela Canindé

Sua vida foi sofrida

A maior luta diária

Era a busca por comida

Uma vida esfomeada

Sempre muito deprimida.

Como era catadora

Pelos lixos encontrava

O papel e o caderno

Que por fim utilizava

Como o famoso Diário

Onde tudo registrava

(ARRAES, 2017, p.37,38,39).

Sobre Maria Carolina de Jesus também pesara o fardo da escravidão que, embora abolida, continuara causando dores como se a condição de livre alcançada por sua mãe não pudesse acarretar mudanças positivas à sua própria condição e à de sua filha. Sua mãe fora humilhada e sequer a Igreja a amparara pois, grávida de um homem casado, ficara só, excomungada e com a filha que nascera em 1914 para criar.

Com 23 anos de idade, Carolina se mudou para São Paulo, e a maior luta que diariamente enfrentava era a busca por comida. Moradora da favela Canindé, seu ofício era o de catadora. Observa-se que a condição periférica - de moradia e de trabalho - parece ser naturalmente compreendida como lugar de destino da população descendente de escravos. Ela, apesar de todo o sofrimento, também se valeu de mecanismos de resistência para, em termos, burlar a condição que lhe estava previamente "determinada". Procede dizer, assim, que a exclusão e opressão experimentadas pelas mulheres negras engloba aspectos do racismo, machismo e preconceitos de classe, incidindo, portanto, sobre elas a exploração, seja do mundo do trabalho, seja da sexualidade. Sobre essa questão, Silva $(2013$, p. 109) pondera que:

As discriminações de raça e gênero produzem efeitos imbricados, ainda que diversos, promovendo experiências distintas na condição de classe e, no 
caso, na vivência da pobreza, a influenciar seus preditores e, consequentemente, suas estratégias de superação. Neste sentido, são as mulheres negras que vivenciam estas duas experiências, aquelas sempre identificadas como ocupantes permanentes da base da hierarquia social.

Para reafirmar o exposto anterior, apresenta-se uma citação que justifica, objetivamente, o surgimento de movimentos de militância em favor da causa da mulher negra ou feminismo negro, pois as demandas dos movimentos femininos à época não contemplavam a realidade dessas mulheres:

No Brasil, a distinção de gênero não pode ser compreendida de modo adequado sem considerar-se a questão racial. Na hierarquia da renda, o primeiro fator determinante é a raça, depois o gênero. As mulheres brancas mantem uma posição nitidamente privilegiada em relação aos homens negros, e as afro-brasileiras estão no mais baixo degrau da escala de renda e emprego. Os homens brancos recebem mais de três vezes o que ganham as mulheres afro-brasileiras, que por sua vez ganham menos da metade do valor da renda mediana da mulher branca (NASCIMENTO, 2003, p. 117).

Portanto, conforme Nascimento (2003), o fator de maior influência na hierarquia da renda é a raça negra, seguido, então, do gênero feminino. A partir de 1980, sobretudo, desenvolveram-se pesquisas que buscaram trazer à tona novos entendimentos sobre a escravidão no Brasil. Nesse sentido, o escravo e seus descendentes foram apresentados como sujeitos partícipes da luta contra a escravidão com as astúcias por eles praticadas - essa era a nova historiografia da escravidão. Nesse trabalho, como se tem destacado, observa-se, em especial, o papel desempenhado pelas mulheres.

As contribuições teóricas e a análise do conteúdo dos cordéis que apresentam as 15 heroínas negras brasileiras da obra de Jarid Arraes ilustram a necessidade ímpar de se trazer para a discussão, nos ambientes escolares, a nova historiografia da escravidão, que propõe o entendimento e reconhecimento da população negra escravizada como sujeitos partícipes da história do país, e agentes que lutaram, com expedientes diversos, por sua liberdade, não mais admitindo que tivessem aceito, com passividade, a situação a que foram submetidos. Esses estudos, como se observou, principiaram na década de 80 e, desde então, os resultados das pesquisas contribuem para abalar o paradigma da ausência do negro na sociedade colonial brasileira.

Buscou-se dar destaque às características de mulheres negras apresentadas como heroínas nos cordéis de Jarid Arraes, revisando aspectos relacionados à condição da mulher escrava no Brasil para dar visibilidade à sua participação na luta pela liberdade dos escravos, 
considerando que, historicamente, foram tratados como objeto/mercadoria e tiveram suas ações suprimidas da história, o que foi referido como o paradigma da ausência do negro nos registros oficiais, sobretudo no que se refere à participação da mulher nesse processo.

Assim, verificou-se, com respaldo de de Certeau (1996), a multiplicidade de táticas empreendidas por essas mulheres que, astuciosas, encontraram meios para burlar o sistema opressor e justificam o título de heroínas que lhes é atribuído pela escritora. Essas táticas englobaram: fugas, fornecimento de alimentos a escravos fugitivos, formação de quilombos, incêndio a plantações, envenenamentos, dissimulações, canto aos orixás, organização de motins, repasse de mensagens via tabuleiro para as negras escravas, instrução, religião, militância política, publicação de livros para as não-escravas; entre outras, que foram identificados nos cordéis da obra aqui analisada.

Esta análise possibilitou reconhecer as expressivas contribuições dos estudos da nova historiografia da escravidão no Brasil para a promoção de um olhar ainda menos tolerante com as consequências da escravidão à população afrodescendente. Sobretudo, a grande contribuição da obra está na valorização que promove à ancestralidade de mulheres descendentes de escravas, pois elas, instruídas acerca da militância de suas antepassadas, tem aumentadas as suas possibilidades de emancipação e empoderamento, apesar das desigualdades de gênero e raça que são herança dura dos tempos amargos da escravidão.

As mulheres personagens protagonistas da obra de Jarid Arraes são personagens de ficção que também se fazem históricas, concretas e complexas cujas dores ainda repercutem no corpo de cada mulher negra, vítima de tantas formas de violência e opressão, desassistida nos seus direitos e ignorada na sua condição de descendente de mulheres bravas e lutadoras. Por isso, a escritura de Arraes, aqui entendida como arte que opera contra a subalternidade, pode ser lida e ouvida também como uma "nova astúcia" para deixar bem evidentes no presente os atos praticados no passado, os quais devem inspirar outras mulheres a se tornaram líderes e heroínas da própria condição.

\section{REFERÊNCIAS}

ARRAES, Jarid. Biografia. Disponível em http://jaridarraes.com/biografia/ Acesso em 20 de abr. 2020.

. Heroínas Negras Brasileiras em 15 Cordéis. São Paulo. Pólen, 2017. 
BRUM, Eliane. Como resistir em tempos brutos. Um manual para enfrentar as próximas três semanas e transformar luto em erbo. Disponível em: https://brasil.elpais.com/brasil/2018/10/08/opinion/1539019640_653931.html. Acesso em 28 jan. 2020.

CERTEAU, Michel de. A invenção do cotidiano: 1, Artes de fazer. Petrópolis: Vozes, 1994. A invenção do quotidiano. Petrópolis, Vozes. 1996.

CHALHOUB S; e SILVA, F. T. da. Sujeitos no imaginário acadêmico: escravos e trabalhadores na historiografia brasileira desde os anos 1980. Cadernos AEL, Campinas, v. 14, n. 26, 2009.

ELTIS, David. Um breve resumo de tráfico transatlântico de escravos - A Travessia do Atlântico. Emory University, 2007. Disponível em: https://slavevoyages.org/voyage/essays\#interpretation/a-brief-overview-of-the-trans-atlanticslave-trade/the-middle-passage/6/pt Acesso em 06 fev.2020.

GIACOMINI, Sonia Maria. Mulher e escrava: Uma Introdução ao Estudo da Mulher Negra no Brasil. Rio de Janeiro: Vozes, 1988.

GONZALEZ, Lélia e HASENBALG, Carlos. Lugar de Negro. Rio de Janeiro: Marco Zero, 1982, (Coleção 2 Pontos).

KARASCH, Mary. A vida dos escravos no Rio de Janeiro (1808-1850). São Paulo: Companhia das Letras, 2000.

MACEDO, Sérgio D. T. Crônica do Negro no Brasil. Record: Rio de Janeiro, 1974.

MAGALHÃES, EKC; GIACOMINI, Sonia Maria. A escrava ama-de-leite: anjo ou demônio? In: Barroso C, Costa AO. Mulher mulheres. São Paulo: Cortez/ Fundação Carlos Chagas, 1983.

MENDES, J. M. de O. O desafio das identidades. In: SANTOS, B. S. (Org.) A globalização e as ciências sociais. São Paulo: Cortez, 2002. p. 503-540.

MOTT, Maria Lúcia de Barros. Submissão e resistência: a mulher escrava na luta contra a escravidão. São Paulo, Contexto, 1988.

NASCIMENTO, Elisa Larkin. O Sortilégio da Cor: identidade raça e gênero no Brasil. São Paulo: Summus, 2003.

RABELO, Danilo. As representações jurídico-policiais sobre a prostituição na Cidade de Goiás (1850). Em Tempo de Histórias, $n^{\circ}$. 6, 2002. Disponível https://periodicos.unb.br/index.php/emtempos/article/view/20173 Acesso em 21 nov. 2019

SCHWARTZ. Stuart. Escravos, roceiros e rebeldes. Bauru, SP: EDUSC, 2001

SILVA, Iraneide Soares da. É preta, é preto em todo canto da cidade: história e imprensa na São Luís/MA (1820 - 1850). 2017. Tese (Doutorado em História, trabalho e movimentos 
sociais), Universidade Federal de Uberlândia, 2017.

SILVA, Tatiana Dias. Mulheres Negras, Pobreza e Desigualdades de Renda. In: MARCONDES, Mariana Mazzini. et al. Dossiê mulheres negras: retrato das condições de vida das mulheres negras no Brasil. Brasília: Ipea, 2013. Cap. IV. p. 109-132.

SPIVAK, Gayatri. Pode o Subalterno falar? Belo Horizonte: Editora UFMG. 2010.

Recebido: $15 / 10 / 2020$

Aprovado: 23/06/2021 